\title{
KIRCHHEIMER ENTRE 1928 E 1933: O PARLAMENTO COMO PRINCIPAL LOCUS DEMOCRÁTICO ${ }^{1}$
}

ESTER GAMMARDELLA RIZZI ${ }^{2}$

RESUMO: É o Parlamento que está em destaque na obra de Otto Kirchheimer sobre a República de Weimar. Quer para criticar a escolha pelo parlamentarismo nas decisões da Assembleia Nacional Constituinte, quer para defendê-lo do Poder Executivo que promovia o saque de suas competências, referendado pelo Poder Judiciário, é essa a instituição que tem centralidade na análise do autor entre 1928 e 1933. Em dois livros e quinze artigos de intervenção política, o significado e a forma de funcionamento do Poder Legislativo para o Estado Alemão eram permanentemente debatidos. Em um primeiro momento, em função da mudança de significado gerada pela possibilidade de representação da classe trabalhadora, só possível após a implementação do fim do voto censitário e da implementação de sua universalidade. Ainda assim, a legalidade e a democracia possíveis no âmbito do Estado de Direito instituído pela Constituição de Weimar eram vistas com desconfiança por Kirchheimer. Só quando a supressão da legalidade - inclusive de sua aparência - corroeu os fundamentos da República de Weimar, Kirchheimer passou a reconhecer inequivocamente um valor emancipatório na forma direito.

PAlaVRAS-ChaVE: Kirchheimer; Parlamento; forma direito; democracia.

Abstract: Parliament is highlighted in Otto Kirchheimer's work on the Weimar Republic. Whether to criticize the choice of parliamentarism system in National Constituent Assembly, or to defend it from the Executive Power that promoted the looting of its powers, this is the institution that has centrality in the author's analysis between 1928 and 1933. In two books and fifteen articles on political intervention, the meaning and the way in which the Legislative Power works were permanently debated. At first, due to the change generated by the possibility of representation of the working class, only possible after the implementation of the universal vote. Even so, the legality and democracy promoted by the Weimar Constitution were viewed with suspicion by Kirchheimer. Only when the suppression of legality -

1 Este artigo é reformulação de reflexões já desenvolvidas no capítulo 2 da dissertação de mestrado Democracia e Transformações Sociais no Estado Parlamentar: Kirchheimer e a República de Weimar, defendida em 2011. A versão integral da dissertação está disponível em:https://www.teses.usp.br/teses/disponiveis/2/2139/tde-24042012-

110644/publico/Ester_Gammardella_Rizzi.pdf. Consulta realizada em 17 dez. 2021.

2 Professora do Curso de Gestão de Políticas Públicas da EACH-USP. Doutora em Filosofia e Teoria Geral do Direito da FD-USP. Contato: ester.rizzi@usp.br. 
including its appearance - eroded the foundations of the Weimar Republic, did Kirchheimer unequivocally recognize an emancipatory value in the Rule of Law form.

KEYWORDS: Kirchheimer; Parliament; democracy; Rule of Law.

\section{INTRODUÇÃO}

Desde há alguns anos tornou-se frequente ler análises que aproximam a situação de crise institucional no Brasil contemporâneo com a instabilidade política da República de Weimar. O desfecho absolutamente trágico do projeto que teve início em 1919 com a instalação da República na Alemanha e a aprovação da Constituição de Weimar, em 11 de agosto do mesmo ano, é lembrado com temor quando são identificadas semelhanças entre os dois períodos históricos. Felizmente, há também muitas diferenças.

Entre as semelhanças, duas constituições que ganham nomes simbólicos e tornam-se protagonistas dos embates político-institucionais que visam a regular: Constituição de Weimar de 1919 e Constituição Cidadã de 1988. Quanto desses textos normativos são responsáveis pelo desenrolar concreto das disputas políticas que se dão nas arenas institucionais criadas por elas? Quanto os desejos de transformação social embutidos em seus textos impulsionam reações violentas e autoritárias em todo contrárias ao que prescrevem suas normas?

No embate entre forças políticas presentes na sociedade e direito que limita e dá contornos à sua possibilidade de ação, além da Constituição está também o Poder Legislativo. Tal poder, símbolo máximo da possibilidade democrática no Estado Parlamentar, parece ser o responsável por acolher e dar vazão institucional de forma contínua aos embates políticos da sociedade e trazê-los para a forma direito.

Otto Kirchheimer (1905-1965), jurista, teórico político e membro do Partido Social-Democrata alemão, pesquisador que posteriormente integrou o Instituto de Pesquisa Social (também conhecido como Escola de Frankfurt), encerrava seu doutorado em 1928, em plena crise da República de Weimar. Kirchheimer, em sua recém-maturidade acadêmica, produziu um conjunto de textos no período entre 1928 e 1933, muitos deles textos de intervenção no debate político-constitucional que lhe era contemporâneo. Neste artigo, de caráter ensaístico, dissecaremos as reflexões que Kirchheimer traz sobre o papel que o Parlamento instituído pela Constituição de Weimar desempenhava naquela realidade.

Mas... por que ler Kirchheimer? Autor judeu que viveu na Alemanha a ascenção do nazismo na década de 1930. Autor que, leitor de Marx e comprometido com desejos de transformação social, discutiu a importância (ou não) do Estado de Direito para a emancipação. Ao debater a importância da forma 
institucional e das garantias do Estado de Direito, sobretudo no momento em que essas mesmas garantias eram desconstruídas, desenvolveu reflexões relevantes para a Teoria do Estado. É exatamente sobre esta produção rica tanto do ponto de vista teórico quanto do ponto de vista histórico e conjuntural que nos debruçamos neste texto.

Kirchheimer descreve e discute um Parlamento amplamente legitimado e empoderado pela Constituição de Weimar, que, porém, instituiu outros legisladores extraordinários (quórum qualificado, Executivo e o art. $48 \mathrm{CW}$, plebiscitos e referendos) sem que esses oferecessem, no entanto, reais limites à ação do Poder Legislativo. Parlamento, afirma Kirchheimer, que não é local de debates racionais capazes de levar a uma melhor escolha, mas mero espaço de posição política e medição de forças sociais para aprovação - ou não - de propostas políticas. Discute ainda sobre a falta de igualdade nas possibilidades de ingresso nesse espaço político, pois haveria formas de concentrar o poder político por meio de artifícios ligados ao poder econômico (como domínio da imprensa ou financiamento de campanhas), formas que não dizem respeito diretamente ao Parlamento, mas o influenciam decisivamente. Por fim, analisa Kirchheimer, mesmo quando se alcançava uma maioria de deputados parlamentares pró-transformações sociais no Reichstag alemão, havia requisitos normativos que "forçavam" coalizões, por meio das quais eram impedidas de serem efetivadas quaisquer propostas de mudanças estruturais: a esfera de distribuição estaria submetida a essa mecânica institucional de exercício do poder, que o afastava da maioria fática (ou, talvez, do poder social). A pergunta de fundo dessas reflexões e análises de Kirchheimer sobre as forças políticas concretas atuando junto ao Parlamento parecia ser: "essa forma de Poder Legislativo, que embute uma promessa de participação democrática, realiza de fato sua promessa? É o Parlamento uma instituição capaz de realizar democracia política?".

Diante dessa sucessão de constatações pouco animadoras sobre as possibilidades de mudança social por meio do Parlamento, é compreensível a posição inicial de Kirchheimer ${ }^{3}$ sobre seu objeto de estudo: a extinção do Parlamento não redundaria - ao menos não necessariamente - em ditadura. Democracia não seria, assim, sinônimo de democracia parlamentar, mediada pela forma direito. Outros caminhos estariam abertos a serem testados. Ao longo do período analisado, porém, ao ver a desfiguração dessa instituição na prática política da Alemanha naquele período - os textos aqui analisados foram escritos entre 1928 e 1933 - Kirchheimer altera sua visão e passa a enxergar o Parlamento e a forma direito como requisitos para a emancipação política e, portanto, talvez o melhor caminho disponível para a democracia com garantia de liberdades. Tais

\footnotetext{
${ }^{3}$ Para informações biográficas sobre o autor ver: RIZZI, Ester Gammardella. Qual é a forma jurídica da nova ordem social? Reflexões a partir da obra de Otto Kirchheimer sobre a Constituição de Weimar. In: Gilberto Bercovici. (Org.). Cem anos da Constituição de Weimar (1919-2019). 1ed. São Paulo: Quartier Latin do Brasil, 2019, v. 1, p. 393-429.
} 
liberdades, por sua vez, passam a ser uma das dimensões importantes da emancipação.

Discutir as consequências, principalmente as más consequências, de um Parlamento que não realiza sua promessa institucional, é quase necessariamente afirmar que em sua promessa reside algum valor. Não seria possível, assim, um teórico dedicar-se extensivamente a um tema e tecer diversas considerações sobre a inefetividade de uma instituição se a ela não atribuísse qualquer importância. É verdade que em praticamente todas as suas obras do período da República de Weimar Kirchheimer passa pela análise do Parlamento. No entanto, mais intensamente a partir de O Artigo 48 e as Modificações do Sistema Constitucional Também uma contribuição para o Dia da Constituição ${ }^{4}$, trabalho que discute o uso abusivo do artigo 48 da Constituição de Weimar para subtrair - ainda que momentaneamente - do Parlamento suas competências constitucionais e transferi-las para o Presidente do Reich, o objeto de suas análises passa a ser o risco que a desfiguração institucional do Parlamento oferece para a sociedade alemã. É em tom de alarme, como para "avisar" a seus contemporâneos dos possíveis impactos do cenário que estava se descortinando, que Kirchheimer escreveu diversos de seus textos posteriores - Reação Constitucional 19325; Reforma Constitucional e Social-Democracia ${ }^{6}$; A Reforma Constitucional ${ }^{7}$; Legalidade $e$ Legitimidade8; Comentários sobre 'Legalidade e Legitimidade' de Carl Schmitt ${ }^{9}$. Chama, assim, a atenção para o processo de deslegitimação política e social do Parlamento, bem como para os interesses que estavam envolvidos nesse processo.

Se em seus textos anteriores Kirchheimer insistia em denunciar a inefetividade da instituição cujo objetivo declarado era produzir direito para, a um só tempo, limitar e democratizar o exercício do poder, desvinculando-o hipoteticamente do poder econômico, a partir de $O$ Artigo 48 e as Modificações do Sistema Constitucional altera-se o tom. $\mathrm{O}$ centro da reflexão não é mais o que é decidido sob a aparência da legalidade do Parlamento, mas sim a supressão até mesmo dessa aparência de legalidade. O Reichstag como instância efetiva de intermediação - ainda que pouco eficaz para limitar as influências de outras esferas de poder social - deixa de existir, e o poder passa a ser exercido diretamente.

Entre ações que respeitam ritos democráticos, nos quais há a observância de processos e normas ainda que insuficientes para realização da democracia, e a desconfirmação total da organização institucional do Estado de Direito e seus instrumentos de controle do exercício do poder, há um caminho que, na República

\footnotetext{
${ }^{4}$ Otto Kirchheimer. Artikel 48 und die Wandlungen des Verfassungssystems (1930). p. 91-95.

${ }^{5}$ Otto Kirchheimer. Verfassungsreaktion 1932 (1932). p. 62-78.

${ }_{6}^{6}$ Otto Kirchheimer. Verfassungsreform und Sozialdemokratie (1933). p. 79-99.

7 Otto Kirchheimer. Die Verfassungsreform (1932). p. 96-112.

8 Otto Kirchheimer. Legalität und Legitimität (1932). p. 7-29.

9 Otto Kirchheimer; Nathan Leites. Bemerkungen zu Carl Schmitts 'Legalität und Legitimität' (1933). p. 113-151.
} 
de Weimar, foi percorrido. Segundo Kirchheimer, assim, fora cruzada a linha entre o poder social mediado por instituições e a sua realização por meios extralegais, que guardam um componente de força.

\section{Do VOTO CENSITÁRIO AO VOTO UNIVERSAL E A MUDANÇA DE SIGNIFICADO DO PARLAMENTO}

Ao descrever as características que marcaram o Estado Parlamentar em sua conformação inicial, Kirchheimer deixa claro o porquê da separação entre Parlamento e democracia que afirma com ênfase no início do texto "Mudança de Significado do Parlamentarismo", de $1928^{10}$ : apenas as classes com propriedades e cultura (posses e formação) poderiam ocupar cargos importantes na administração pública. Tal requisito afastava o Estado Parlamentar de qualquer pretensão popular ou democrática; aqueles que efetivamente exerciam o governo deveriam pertencer às classes mais altas da sociedade. Além dessa característica, havia uma crença racionalista de que o Parlamento seria o local privilegiado para realizar discussões capazes de "fazer emergir" as melhores decisões políticas a serem tomadas e, por fim, o Estado de Direito, como regra de equalização do tratamento de todos frente à lei e às ações governamentais, arrematava as características legitimadoras de sua forma específica de dominação.

O que apontamos como o primeiro princípio do Estado burguêsparlamentar acabou por de fato cair. $\mathrm{O}$ voto censitário era o meio mais ingênuo de manter grandes camadas de eleitores afastadas. Mas seria um ponto de vista demasiadamente superficial se nos contentássemos com a constatação de que desapareceu um meio de afastar as camadas proletárias da representação enérgica de seu interesse de classe, sem nos preocuparmos em perguntar se o objetivo almejado não é hoje alcançado por outros meios. No século XX, a burguesia aprendeu a se servir de um poder muito efetivo, que ela não conhecia anteriormente nessa extensão e do qual não tinha sentido necessidade de se servir de maneira organizacional antes. Com ajuda do dinheiro, ela criou um grande número de instituições por meio das quais ela falsifica a formação da vontade estatal. Seu meio mais importante é sua imprensa. Para mostrar a vantagem descomunal que a burguesia consegue em razão do capital que está à sua disposição, basta apontar para um exemplo familiar a todos nós. Existe hoje uma organização influente chamada Partido Democrático (Demokratische Partei) - em razão de sua ideologia, ela é muito mais perigosa para o operariado do

${ }^{10}$ Kirchheimer, O., \& Tavolari, B. (2018). Mudança de significado do parlamentarismo. Cadernos De Filosofia Alemã: Crítica E Modernidade, 23(1), 155-159. https://doi.org/10.11606/issn.23189800.v23i1 
que seus inimigos públicos; mas infelizmente ainda não ficou suficientemente claro para os círculos dirigentes do partido que, por um lado, o capital financeiro e, por outro, industriais e agrários, por mais que possam não concordar em muitos pontos, têm exatamente a mesma opinião no ponto decisivo, o da manutenção da propriedade privada e da liberdade de contrato. Essa organização política, o Partido Democrático, deve sua existência somente às três empresas jornalísticas: Ullstein, Mosse e Frankfurter Sozietätsdruckerei. Por meio de sua posição de poder financeiro, a burguesia assumiu uma posição de poder velada no lugar de uma posição aberta. Ela concedeu o direito de voto igual e universal para, ao mesmo tempo, despojá-lo de seus mais importantes efeitos por meio da sua posição de poder

O voto universal, em oposição ao voto censitário, foi inovação histórica que mitigou a disposição de limitar o acesso às posições determinantes da estrutura governamental às classes possuidoras de propriedade e cultura. Segundo Santos ${ }^{11}$ (1998), o voto universal instituído desde as eleições para a Assembléia Constituinte de 1919 na Alemanha representou um aumento de 158\% no colégio eleitoral. Ou seja: mais do que dobrou o total da população apta a votar. Todos, homens e mulheres, poderiam votar e se candidatar aos cargos públicos. No entanto, essa inovação - que poderia conferir caráter democrático ao que Kirchheimer chamava de Parlamentarismo - foi substituída por outros mecanismos que impediam o acesso às posições que exercem funções políticas e à participação nas decisões relevantes. $\mathrm{O}$ voto censitário, segundo ele, teria sido a maneira mais ingênua de atingir o objetivo, que permaneceu o mesmo, tendo sido modificada somente a forma de alcançá-lo.

Foi por meio do poder econômico e do sofisticado controle da imprensa que a burguesia teria permanecido em seu posto privilegiado de poder, embora esse não mais lhe fosse assegurado institucionalmente. A influência decisiva sobre os debates públicos tinha êxito no objetivo de aproximar a vontade estatal de sua própria vontade, mantendo-se em posição de dominação, ainda que não explícita. Ao aprimorar as formas de alcance do poder, a burguesia dominante podia conviver pacificamente com o direito ao voto universal que, segundo Kirchheimer, tinha sido alijado de boa parte de seu sentido político.

Se o título do texto de Kirchheimer indica a mudança do significado do Parlamentarismo e se em sua origem tal forma de organização estatal tinha uma clara face burguesa, a primeira alteração apresentada não traz esperança: transforma-se para continuar igual. A burguesia traça meios alternativos para se manter em posição de poder.

${ }^{11}$ Wanderley Guilherme dos Santos. Poliarquia 3 D. Revista Dados 41 (2) • 1998 Disponível em: https://www.scielo.br/j/dados/a/H5WXcbFfmrpb8VwyckmqhnC/?lang=pt\# 
Na melhor das hipóteses, a unidade do parlamento era a unidade do front daqueles que não estavam satisfeitos com o sistema dominante. A unidade foi rompida no instante em que o inimigo comum, a monarquia semi-feudal, desapareceu e o poder tão ardentemente almejado foi finalmente alcançado com ao menos meio século de atraso. Com a unidade do parlamento, também desapareceu seu poder. ${ }^{12}$ (Weimar... e então?, 1930)

Além do voto censitário, que dividia os cidadãos - homens - alemães em três classes distintas, para as quais eram atribuídos pesos distintos nas votações, o Parlamento que tal sistema elegia também era extremamente frágil antes de 1918. Sua principal atuação tinha caráter negativo, traduzindo-se no poder de vetar orçamentos. ${ }^{13}$ Ainda assim, como havia um "inimigo comum" para boa parte dos parlamentares que defendiam a importância política da instituição à qual estavam vinculados - a monarquia, que impedia quaisquer pretensões de outras decisões políticas relevantes -, a força do Parlamento era derivada da união contra um sistema político que lhe tolhia competências.

O irônico, assim, é que ao mesmo tempo em que o Parlamento ganhou força institucional no sistema político alemão pós-Constituição de Weimar de 1919, ele perdeu força política em decorrência do esfacelamento de sua antiga unidade de oposição em múltiplas facções e tendências políticas internas. Ao menos tal é a análise que Kirchheimer faz, retrospectivamente, em Weimar... e então?, obra de 1930.

Consequência relevante da entrada do proletariado no Parlamento foi este ter deixado de ser considerado um local próprio das discussões racionais capazes de alcançar e desvendar a melhor decisão política para determinada situação. Kirchheimer afirma que as decisões políticas passaram a ser tomadas em momentos - e espaços - outros que não os de participação no próprio Parlamento. Afirma ainda que este se tornou um local de declarações de posições, e não de discussões efetivas. Quando há a entrada de uma classe social cuja racionalidade e posicionamentos para a organização da sociedade são significativamente distintos de outras, rui a possibilidade de, por meio da discussão racional, chegarse a uma decisão consensual ou evidentemente majoritária.

Proletariado e burguesia parecem ter interesses opostos e visões contraditórias sobre a forma desejável de organização política. Sendo seus pressupostos e objetivos distintos, a discussão não se faz produtiva, não há possibilidade de convencimento, mas tão somente reafirmação de posições conflitantes. A decisão

12 Otto Kirchheimer. Weimar... e então? Formação e atualidade da Constituição de Weimar. Tradução de Bianca Tavolari. Direito e Práxis, n. 2, v. 10, 2019. P. 1530.

${ }^{13}$ Otto Kirchheimer. Weimar... e então? Formação e atualidade da Constituição de Weimar. Tradução de Bianca Tavolari. Direito e Práxis, n. 2, v. 10, 2019. P. 1529. 
final e a efetiva ação na realidade é tomada pelo grupo que tem maior poder na sociedade. Alerta Kirchheimer, porém, que tal poder social não necessariamente coincide com a maioria parlamentar.

Sobre a idealização inicial da composição do Parlamento por "classes de propriedade e cultura", capazes de alcançar as decisões políticas mais racionais para uma dada comunidade política, em Weimar... e então? (1930), Kirchheimer comenta outra função que se associava - e a referência citada para tal associação era Weber - ao Parlamento: ser um local para seleção de líderes ${ }^{14}$. Critica a visão funcional ingênua de quem o assim descreve: essa função só poderia ser desempenhada em um Poder Legislativo no qual prevalecesse a coesão e homogeneidade dos membros, com uma classe evidentemente predominante. Em um ambiente em que há pluralidade de forças sociais representadas, não há tempo para "seleção natural" de líderes. As lideranças já devem estar lá, preparadas para o confronto com interesses conflitantes.

A constatação de que não há apenas uma racionalidade possível, mas que podem ser várias, a depender do fim que se quer alcançar, aliada à afirmação de que objetivos distintos ensejam caminhos racionais distintos para os atingir - e de que os objetivos por si só representam valores, já que, em última instância, não seriam concluídos racionalmente, no que segue Weber -, leva o debate sobre as possibilidades efetivas de deliberação no Parlamento a se colocar em outro patamar. É nesse contexto que surge a possível necessidade de uma homogeneidade política para o "apropriado" funcionamento do sistema.

A burguesia do século XIX possuía, do ponto de vista de Kirchheimer, um tal acordo de objetivos que a discussão no Parlamento versava efetivamente sobre quais os melhores caminhos para alcançá-los. O que estava em pauta eram os meios para se atingir um determinado objetivo, consensual entre os que participavam da discussão. O debate no Poder Legislativo se torna muito mais complexo quando os objetivos finais são distintos. Trata-se, juntamente com a factibilidade das estratégias, de discutir os fins em si mesmo considerados. E, como tal debate não se dá totalmente em bases racionais, torna-se uma disputa na qual o que está em jogo é "ganhar ou perder" o delineamento geral da política ou da concepção de sociedade.

Quando Kirchheimer desconstitui o Parlamento como espaço de debate racional e desloca a explicação do seu mecanismo de funcionamento para uma teoria "realista" de embate de poder social, desconstrói parte significativa do fundamento de legitimidade que o sustentaria. Se a intermediação institucional não traz nenhum avanço na concepção da norma formulada, se há decisões prévias que procuram maior quantidade de votos para serem aprovadas, o que

${ }^{14}$ Otto Kirchheimer. Weimar... e então? Formação e atualidade da Constituição de Weimar. Tradução de Bianca Tavolari. Direito e Práxis, n. 2, v. 10, 2019. P. 1531. 
justificaria, então, a existência do Parlamento? Apenas ser um procedimento para auferir de qual lado, a favor de qual proposta, se encontra a maioria? ${ }^{15}$

Kirchheimer deixa, ao menos em suas obras iniciais, tais perguntas sem resposta. Aponta o vício que há no fundamento de legitimidade da instituição e, em seu lugar, nenhuma alternativa.

\section{PARlamentarisMo - MOMENTO INTERMEDiÁRIO ENTRE A MONARQUIA AUTORITÁRIA E A DEMOCRACIA SOCIAL}

O Parlamentarismo caracteriza-se, segundo Kirchheimer, por ser a forma de Estado usada pela burguesia ascendente para acabar com os privilégios da nobreza e com as monarquias absolutistas. Ambas impunham à burguesia, que se tornou economicamente dominante, ônus aos quais ela não mais estava disposta a se submeter. Forma de organização do Estado burguesa, no entanto, não significa forma de organização do Estado popular e democrática. Entre o autoritarismo monárquico e o Estado democrático popular há, segundo Kirchheimer, o Estado Parlamentar burguês, que com nenhum dos dois precedentes se identificaria.

Sentencia finalmente Kirchheimer sua avaliação final sobre o Estado Parlamentar de 1928, em texto sobre a Teoria do Estado do Socialismo e do Bolchevismo ${ }^{16}$ : é uma forma organizacional de transição. Identifica um momento histórico no qual nem a burguesia é tão forte a ponto de resgatar seus antigos privilégios e exclusividades no exercício do poder, nem o proletariado tem tanta força social a ponto de impor uma forma de organização social e do poder que lhe seja mais adequada. É este impasse político, em que há um equilíbrio de forças considerável a ponto de nenhuma ser capaz de sujeitar completamente a outra, que garante a sobrevivência do Estado parlamentar.

\footnotetext{
${ }^{15}$ No mesmo sentido, Angelo Bolaffi. Il Crepuscolo della Sovranità. p. 24-25, 2002: “Ma quali sono allora i veri principi 'spirituali' del parlamentarismo? La discussione publica e la Offentlichkeit: il government by discussion e la fine degli arcana rei publicae. Pubblicità dell'opinione e opinione pubblica, difesa della libertà di parola e tutti gli altri principi constituzionale, segretezza del voto. Questa è la dialettica del parlamentarismo liberale: 'la libertà dell'opinione è una libertà di privati; essa è necessaria per la concorrenza delle opinioni nella quale la migliore trionfa'. La diskutierende Öffentlichkeit perviene alla veritas la quale a sua volta facit legem. L'autorità è risolta nella verità del confronto dialettico di opinioni. Da questo discende il carattere generale e universale della forma di legge e il balance of powers. Ma tale procedimento che garantisce la verità della legge presuppone che nella discussione si confrontino opinioni disinteressate e non contrapposti interessi organizzati, e quindi una relativa omogeneità del corpo elettorale e dei suoi rappresentanti: è esattamente la condizione che viene vanificata dallo sviluppo della Massendemokratie. Se infatti ‘le leggi risultano dalla lotta di opinioni (e non dalla lotta di interessi)', questo è possibile perchè alla discussione sono presuposti quali 'premesse', comuni convinzioni, disponibilità a lasciarsi convincere, indipendennza daí legami partitici e imparzialità rispetto a interessi egoistici. Ma non appena si manifesta 'l'eterogeneità dei fini' l'epoca della discussione è finita."

${ }^{16}$ Otto Kirchheimer. Zur Staatslehre des Sozialismus und Bolschewismus (1928).
} 
Ao mesmo tempo em que vislumbra esse potencial político, Kirchheimer arremata o trecho indicando uma concepção específica do perfil institucional recém-traçado: a tensão entre trabalhador e burguesia trazida para os limites institucionais do Parlamento e para a forma jurídica neutralizadora de conflitos é apenas provisória. Em algum ponto do futuro, finalmente o proletariado conseguirá se impor sobre a burguesia, totalmente. Ou o contrário, a burguesia impor-se-á sobre o proletariado.

A posição de equilíbrio seria, assim, instável e improvável. Superada a instabilidade do momento transitório, parece antever Kirchheimer, abrir-se-á mão também da instituição Parlamento e, quiçá, da forma direito que o acompanha.

A burguesia procurou se aproveitar da ideia do Estado de direito em relação ao proletariado de tal maneira a apontar que as leis seriam iguais para todos, que teriam validade igual e que, por isso, o proletariado não poderia exigir um tratamento especial. Contra este argumento basta fazer referência às palavras acertadas de Anatole France: “Em sua justiça majestática, a lei permite que pobres e ricos possam dormir debaixo de pontes". Na verdade, a ideia de Estado de direito ganhou hoje um sentido completamente diferente. Ela não é mais uma posição que pertence exclusivamente à burguesia, nem uma posição de ataque, como em seu período inicial, nem uma posição de defesa, como em seu período tardio. Hoje, a ideia de Estado de direito está situada entre proletariado e burguesia. Ela se tornou a linha divisória de dois grupos em luta, da qual ambos estão bastante distantes para sentir que ela seria a lei definitiva para a distribuição de poder. Isso deve ser ilustrado por meio de um exemplo. Hoje, nem empregadores nem empregados querem colocar tudo em jogo por meio de uma desavença individual; isso porque, hoje, cada uma de suas desavenças ultrapassa a luta de dois indivíduos isolados; por trás de cada um deles está seu grupo social, preparado para vir em ajuda a seu partido em cada caso importante; por isso o Estado estabeleceu todo um sistema jurídico que serve para resolver essas lutas sociais por meio de um caminho jurídico, para retirá-las da esfera dos participantes diretos, para neutralizar questões sociais de poder na forma de problemas de aplicação do direito. Então o sistema jurídico estatal tem hoje a função de criar um estado de equilíbrio nas relações entre burguesia e proletariado. O Estado de direito é, talvez, uma das formas externamente mais características para o valor de transição de nosso sistema político atual, para seu caráter provisório, para uma situação em que uma das classes já não é mais forte o suficiente, a outra ainda não é forte o suficiente 
para manter a exclusividade de seu sistema político. ${ }^{17}$ (Mudança de Significado do Parlamentarismo, 1928)

Em Reação Constitucional 1932 (1932) ${ }^{18}$, Kirchheimer ressalta inicialmente o caráter histórico da forma de organização do poder estatal por meio do Parlamento. Sendo histórico, está vinculado a outras características também históricas do período: o Parlamento é o sistema político que convive com estruturas econômicas concentradoras típicas do capitalismo, afirma, e com uma organização social que não favorece a democracia. O que haveria nele, assim, de abstratamente defensável, ou qual seria o avanço a-histórico a ser defendido? Aparentemente, nada. O Estado socialista, defendido pelo autor, não teria nada a aprender com a forma de organização estatal parlamentar típica e reconhecidamente burguesa. Além disso, o fim do Parlamento não significa o advento da ditadura, afinal - como já havia afirmado -, democracia e Parlamentarismo não se identificam. Parece faltar a Kirchheimer, no entanto, a reflexão histórica sobre o contexto de formulação do Parlamento e quem era o seu inimigo anterior. Que avanço o Parlamento promoveu na história moderna para que fosse identificado com democracia? Se não há Poder Legislativo - e leis gerais - capaz de se colocar entre a vontade política de alguns e a realidade, o que impediria o exercício arbitrário do poder?

\section{COMPETÊNCIAS LIMITADAS (OS LEGISLADORES EXTRAORDINÁRIOS)}

No momento em que o Partido Social Democrata Alemão atinge a maioria no âmbito do Parlamento, em 1912, a solução burguesa passa a ser diminuir a importância desta instituição política, transferindo partes dos poderes que um dia foram de sua competência para outras instituições sociais. Uma das maneiras de manter o poder, no momento em que ele é efetivamente disputado no seio do Parlamento, é diminuir a importância dessa instituição para a realização do poder social e das efetivas decisões políticas fundamentais. Esse processo, que parece ter ocorrido em Weimar, será analisado mais adiante.

O Estado de Direito é, tal como descrito por Kirchheimer, o mecanismo que difunde a ideia de igualdade formal perante a lei e também o terceiro pilar do Estado parlamentar. Uma vez que todos se submetem às mesmas leis, ninguém poderia alegar como fonte de injustiça o tratamento diferenciado conferido pelo Estado. Tal fundamento de legitimidade, ao contrário dos dois primeiros, parece não ter sofrido grande transformação em função das mudanças históricas, como já explicitado em texto citado na seção anterior. A igualdade formal continuaria sendo elemento caracterizador, e fundamento de legitimidade, do Estado

${ }^{17}$ Kirchheimer, O., \& Tavolari, B. (2018). Mudança de significado do parlamentarismo. Cadernos De Filosofia Alemã: Crítica E Modernidade, 23(1), 155-159. https://doi.org/10.11606/issn.23189800.v23i1 p. 157-158

${ }^{18}$ Otto Kirchheimer. Verfassungsreaktion 1932 (1932). p. 62-78. 
parlamentar, de forma muito semelhante ao que era quando das primeiras reflexões teóricas sobre o papel do Parlamento e da separação de poderes.

Em Weimar... e então? (1930) Kirchheimer identifica duas tarefas prometidas pelo Parlamento: realizar a democracia e traduzir suas decisões em efetivas práticas governamentais, a serem levadas a cabo pelo Poder Executivo. Contra modelos distintos de organização política e distribuição do poder - formuladas e, em alguma medida, testadas na União Soviética, e propostas na Assembleia Nacional Constituinte alemã pelos social-democratas independentes (USPD) - o Parlamento foi introduzido com amplos poderes, mas também com amplas pretensões e responsabilidades. O Parlamento é a instituição, afirma Kirchheimer, que concentra a maior capacidade de incidência política, quando comparado aos outros órgãos de poder da República de Weimar.

Carl Schmitt, em Legalidade e Legitimidade, expõe o que considera serem limitadores do poder do Parlamento, na forma de três legisladores extraordinários ${ }^{19}$. Sustenta Schmitt a tese de que um dos graves problemas que pairavam sobre a ordem constitucional de Weimar seria exatamente o de ter criado demasiados contrapesos ao poder do Parlamento, o que traria como consequência a diminuição de sua força decisória. Nessa controvérsia, Kirchheimer se coloca no pólo oposto: ainda que houvesse alguns limitantes constitucionais ao poder do Reichstag, eles não eram suficientes para, na prática política, limitar seus poderes.

A pouca resistência oferecida ao Parlamento pelos demais órgãos dotados de poder constitucional fez que o espaço de ação daquele se apresentasse como visivelmente muito amplo. As grandes possibilidades constitucionais de que dispunha o Parlamento acabaram motivando discussões sobre seu papel de liderança política e sobre a própria viabilidade desta. ${ }^{20}$ (Weimar... e então?, 1930)

Para Kirchheimer não seria, assim, o desenho institucional previsto na Constituição de Weimar o responsável por enfraquecer seu poder. A causa desse enfraquecimento estaria na própria disputa política junto à sociedade. Composição de governos mediada por partidos e indicação de presidentes e

${ }^{19}$ Carl Schmitt. Legalidad y Legitimidad. Trad. José Diaz García. Madrid: Aguilar, 1971. p. 63-114 (Original Legalität und Legitimität, publicado em 1932).

${ }^{20}$ Otto Kirchheimer. Weimar - und was dann? Analyse einer Verfassung (1930). p. 27. Trad. Yuri Luz. No original alemão: “Das geringe Widerstand, den das Parlament an den anderen, nach dem geschriebenen Verfassungsrecht massgebenden Faktoren findet, lässt anscheinend seiner Betätigung weiten Spielraum. Die grossen verfassungsrechtlichen Möglichkeiten, die das Parlament besitzt, haben zu Erörterungen seiner politischen Führerrolle und des Verhältnisses von politischem Führer und Parlament zueinander Anlass gegeben." 
ministros para funções-chave da burocracia alemã - como o Presidente das Ferrovias e o Presidente do Banco Central - impediam que reivindicações importantes da classe trabalhadora, embora com representação majoritária no Parlamento, fossem efetivadas. A esfera de distribuição da riqueza estaria, assim, segundo Kirchheimer, submetida à esfera de direção política. E essa não necessariamente se submetia à direção do Parlamento.

Tais mecanismos político-sociais de afastamento ou impedimento do exercício do poder, no momento em que Kirchheimer escreve Weimar... e então?, em 1930, só reforçam seu argumento de deslegitimação da instituição: se, mesmo obtendose a difícil maioria, há instrumentos capazes de obstar que a maioria seja revertida em decisões políticas práticas a serem implementadas por um governo, qual o sentido do Parlamento? O realismo da análise "o que importam são as reais forças de poder presentes na sociedade" é reforçado por essa análise do contexto político.

As normas gerais - editadas pelo Reichstag - têm um papel importante para todos os órgãos da administração pública de Weimar. Em Legalidade e Legitimidade, Kirchheimer desce à minúcia de uma específica instituição: a polícia. Quais organizações e atos políticos mereciam repressão? Aqueles que efetivamente organizam atividades conflitantes com o disposto em normas gerais, estabelecidas pelo Parlamento, ou seja, aqueles que têm suas ações avaliadas pelo ordenamento jurídico como ilegais, ou os partidos que os policiais consideram ilegítimos e ilegais? A teoria constitucional afirma a primeira linha de resposta; a prática da polícia alemã no final da República de Weimar parece confirmar a segunda, especialmente quando se coloca em questão as atividades do Partido Comunista Alemão (KPD) e do Partido Nacional-Socialista.

Quando o critério para reprimir ações políticas passa a ser a avaliação de legitimidade ou de legalidade feita pelo próprio agente estatal - ou, de forma mais coletiva, de uma de suas corporações, órgãos ou instituições, como é o caso da polícia - perde-se a referência da estrita legalidade, à qual tais agentes deveriam estar vinculados. Pouco importa o que o policial considera correto ou incorreto, sua percepção do que deveria ser legal ou ilegal. Ele deve ser um agente em nome de uma legalidade que não é produzida por ele, mas por pessoas que não exercem sua função. Assim, a ação da polícia, bem como de outros agentes que exercem efetivamente o poder, é controlada e limitada no Estado de Direito pela heteroautoria dos distintos atos de poder do Estado: produção normativa e aplicação da norma por meio do exercício direto do poder.

Kirchheimer ressalta ainda um postulado do direito administrativo que, à época, foi usado contra a observância das normas: a presunção de legalidade de todos os atos dos agentes públicos. Para o bom funcionamento e exercício das funções administrativas, os servidores públicos gozam da presunção de veracidade nas suas declarações e legalidade em seus atos. No entanto, tal prerrogativa não poderia ser absoluta, pois é também elemento essencial do Estado de Direito que haja uma instância recursal, para onde os atos questionados 
possam ser encaminhados e sua legalidade confrontada com o ordenamento jurídico preexistente: o Poder Judiciário. Não podendo tal questionamento ser feito, ou, por outro lado, sendo completamente ineficaz - uma vez que o Judiciário nunca revê ou condena os atos da administração, ou, visto de outra perspectiva, sempre os ratifica - não há mais legalidade possível. Ainda que existam normas gerais prévias, ainda que haja uma determinação constitucional para que todos os agentes públicos ajam de acordo com a legalidade, não existindo uma instância que averigue a adequação entre atos e normas, então não há mais controle do exercício do poder por meio da legalidade. O Poder Judiciário não pode se recusar a exercer sua função de controle, pois, nesse caso, estaria simplesmente se fundindo ao Poder Executivo para reconhecer em todos os casos a legalidade de seus atos.

No momento em que a legalidade é confrontada com a presunção de legalidade que reveste todos os atos públicos, e não pode ser verificada ou questionada, parece se encerrar o fundamento de legitimidade de todo o Estado de Direito e esvaziar-se, concomitantemente, o direito de sua função primordial.

Apesar de ilustrarem algo que diz respeito à forma de organização do poder estatal como um todo, as ações têm como seu principal alvo o Poder Legislativo e, consequentemente, as normas gerais que este tem por competência elaborar. São normas gerais anteriores e Parlamento que perdem a razão de ser quando as próprias instituições executivas passam a decidir quais são os critérios e os parâmetros para suas ações.

Independentemente de qual tenha sido a composição do Parlamento desde sua fundação pela "Revolução Gloriosa", bem como de quais tenham sido as correntes sociais privilegiadas por ele ou dele excluídas, existe uma especificidade sua que nunca foi questionada desde então: a sua necessária colaboração no processo de elaboração legislativa. Se o novo Parlamento não for limitado apenas pelo direito do Presidente-Ditador de decretar medidas e de, por meio delas, legislar autonomamente, mas também lhe for praticamente retirada a possibilidade de revogar tais leis presidenciais, então a função legislativa parlamentar restará, com isto, eliminada. Isto ocorre porque, havendo ainda uma possibilidade jurídica de concorrência entre Presidente e Parlamento, este peculiar projeto de constituição ainda cria uma união pessoal entre o terceiro neutro e o Presidente, na medida em que controle e prática constitucional permanecem nele unidos e concentrados. Uma facticidade do poder legislativo do Parlamento pode ser concebida como algo maior do que um mero ato de compaixão do Presidente, Dado que, para este Parlamento, a possibilidade de se dar a um ministério um voto de desconfiança é de tal forma restrita que ela, em condições de funcionamento 
normal deste Estado, tende a nunca ocorrer, existe aqui, em realidade, apenas um Parlamento no sentido de um "constitucionalismo aparente", tal qual conceituado por Max Weber o regime da Rússia czarista de 1905 a 1917(...). Ao conceito de "poder estatal" é preciso incluir a ideia de "processo legislativo", se não quisermos encampar a teoria fascista segundo a qual "l'atto procede la norma" (o ato precede à norma), aceitando, por consequência, a própria eliminação das normas dotadas de caráter geral. A função de um Parlamento, em um contexto de constitucionalismo aparente, consiste meramente na conservação (ainda que com resultados muito duvidosos) da crença nesta própria função. ${ }^{21}$ (Reação Constitucional 1932, 1932)

Em Reação Constitucional 1932 - último texto escrito em 1932, seguido pelos últimos quatro artigos do período, de $1933^{22}$ - Kirchheimer aponta um dos elementos mais preocupantes da modificação da prática política no que viriam a ser os últimos momentos da República: a apropriação da função legislativa pelo

${ }^{21}$ Otto Kirchheimer. Verfassungsreaktion 1932 (1932). p. 71-72. Trad. Yuri Luz, não publicada. No original alemão: “Denn wie auch immer das Parlament seit der Begründung seiner Eigenständigkeit in der 'glorious revolution' zusammengesetzt gewesen sei mag, welche soziale Strömungen in ihm priviligiert oder ausgeschlissen wurden, eine Eigenschaft wurde ihm seit jener Zeit kaum mehr streitig gemacht: die seiner notwendigen Mitwirkung bei der Gesetzgebung. Wenn das neue Parlament nicht nur durch das Recht des Diktatorpräsidenten, Maßnahmen zu erlassen, und durch dessen selbständiges Gesetzgebungsrecht beschränkt wird, sondern ihm dazu auch noch die Möglichkeit, diese Präsidialgesetze aufzuheben, praktisch genommen wird, so wird damit die legislative Funktion des Parlaments beseitigt. Dies triet dadurch ein, dass bei der juristisch noch möglichen eigenartigen Konkurrenz zwischen Präsident und Parlament dieser einzigartigen Verfassungsentwurf auch noch eine Personalunion zwischen neutralem Dritten und Präsidenten schäfft, insofern Verfassungskontrolle und Verfassungsanwendung bei ihm vereinigt sind (controle constitucional e utilização constitucional unidos). Eine Fakzität des Gesetzgebungsrechts des Parlaments ist nur mehr als Gnadeakt (ato de compaixão) des Präsidenten möglich. Da diesem Parlament überdies die Möglichkeit, dem Ministerium ein Misstrauensvotum zu erteilen, so beschnitten wird, dass es wohl im normalen Betrieb dieses Staates nie zustande kommen kann, liegt in Wirklichkeit hier nur noch ein Parlament im Sinne des von Max Weber für das zaristische Russland von 1905 bis 1917 geprägten Begriffs des Scheinkonstitutionalismus vor. (...) In den Begriff 'Staatsgewalt' müsste man doch eigentlich, wenn man nicht die faschistische Theorie, dass 'l'atto procede la norma' (die Handlung geht dem Gesetz voraus) zur äusserten Konsequenz der Eliminierung genereller Normen überhaupt treiben will, die Gesetzgebung mit einbeziehen. Die Funktion eines Parlaments vom Typ des Scheinkonstitutionalismus besteht bekanntlich lediglich in einer, allerdings im Erfolg sehr zweifelhaften, Konservierung des Glaubens an seine Funktion."

${ }^{22}$ Comentários sobre 'Legalidade e Legitimidade' de Carl Schmitt; Reforma Constitucional e SocialDemocracia; Marxismo, Ditadura e Forma de Organização do Proletariado; Ascensão e Queda da Constituição de Weimar, todos de 1933. 
Poder Executivo. O Parlamento, afirma, tem como competência precípua a participação decisiva no processo de elaboração legislativa. Tal competência justifica-se no sistema pela necessidade de haver uma norma prévia ao ato de exercício de poder que, por sua vez, não deve ser realizado pelo mesmo agente que produziu a norma. Tanto a anterioridade da lei em relação à sua implementação prática, quanto a necessidade de esses dois atos - formulação legislativa e realização executiva - serem realizados por agentes distintos (heteroautoria dos atos legislativo e executivo) são pressupostos necessários à específica forma de legitimação do Estado de Direito, características que, em alguma medida, garantem que o exercício do poder não seja arbitrário.

Quando a possibilidade de legislar do Parlamento depende da graça/generosidade/clemência (Gnade) do chefe do Poder Executivo, a própria organização do Estado de Direito é colocada em xeque. Nesse caso, afirma o autor citando uma análise que Weber fez em outro contexto histórico, trata-se apenas de um aparente constitucionalismo, um aparente Estado de Direito com limitações ao exercício arbitrário do poder, uma vez que o mesmo órgão que age detém o controle de seus atos e, nesses termos, não há efetiva limitação, nenhum objeto podendo ser retirado de seu âmbito de deliberação. Ilimitado o poder, abrese o caminho para sua arbitrariedade. A possibilidade de legislar, bem como de ter sua produção respeitada pelo Poder Executivo, é o traço essencial que não pode ser subtraído do Parlamento, sob pena de torná-lo sem sentido, aqui incluída sua capacidade de revogar os atos normativos editados pelo Poder Executivo durante a vigência do estado de exceção instaurado pelo artigo 48.

O artigo $48^{23}$ da Constituição de Weimar oferecia a possibilidade de suspensão de vários direitos fundamentais, em situações excepcionais de descumprimento de normas constitucionais por um Estado federado e para proteger a segurança e a ordem públicas. Desse modo, poderiam ser suspensas a regra genérica da liberdade, que determina que tudo o que não está proibido em lei é implicitamente permitido, ou seja, a liberdade só pode ser restrita por meio de normas do ordenamento jurídico; a inviolabilidade do domicílio; o sigilo de correspondência; as liberdades de pensamento, expressão, reunião e associação; e as eleições livres e diretas. No entanto, tanto as medidas tomadas durante a suspensão, como também a suspensão em si, deveriam ser notificadas ao Parlamento, que poderia, por meio de uma votação em maioria simples,

\footnotetext{
${ }^{23}$ Artigos que podiam ter sua validade suspensa durante a vigência do estado de exceção do artigo 48, todos da Constituição de Weimar: Artigo 114 Liberdade individual, que só pode ser restrita por meio de lei; princípio da legalidade - tudo o que não é proibido em lei é implicitamente permitido pelo ordenamento jurídico [Freiheit der Person]; Artigo 115 Inviolabilidade de domicílio [Unverletzlichkeit der Wohnung]; Artigo 117 Sigilo de correspondência [Briefgeheimnis]; Artigo 118 Liberdade de pensamento e expressão, nos limites das leis gerais [Meinungsfreiheit, Zensur]; Artigo 123 Liberdade de reunião [Versammlungsfreiheit]; Artigo 124 Liberdade de associação [Vereinigungsfreiheit]; Artigo 125 Eleições livres e secretas [Wahlfreiheit, Wahlgeheimnis].
} 
suspender suas eficácias. Medidas tomadas durante o estado de exceção, bem como a necessidade ou não de manutenção do estado de exceção, deveriam passar pelo crivo do Parlamento, que tem competência para ratificá-las ou suprimi-las. Esse é o poder que lhe restaria quando as normas constitucionais fossem suspensas por tal situação excepcional:

Art. 48 CW [Medidas contra Perturbação da Segurança e da Ordem Públicas]

1. Se um Estado (Land) não cumprir as obrigações impostas pela Constituição ou pelas leis do Reich, o Presidente poderá recorrer às Forças Armadas para obrigá-lo.

2. No caso da segurança e ordem públicas estarem seriamente ameaçadas ou perturbadas, o Presidente do Reich pode tomar as medidas necessárias para restabelecer a lei e a ordem, e, se necessário, com auxílio das Forças Armadas. Para alcançar esse objetivo, poderá suspender os direitos civis descritos nos artigos $114,115,117,118,123,124$ e 154, total ou parcialmente.

3. O Presidente do Reich deve informar imediatamente ao Reichstag sobre as medidas tomadas com base nos incisos 1 e 2 do presente artigo. As medidas podem ser suspensas por determinação do Reichstag.

4. Se o perigo for iminente, o governo do Estado pode, em seu específico território, implementar medidas como a descrita no inciso 2. As medidas podem ser suspensas por determinação do Presidente do Reich ou do Reichstag. ${ }^{24}$

O fato de não restar ao Parlamento nem mesmo a possibilidade de verificar a legalidade e a necessidade da continuidade do estado de exceção, bem como de suas medidas, indicava que, já em 1932, o que existia na Alemanha era apenas

\footnotetext{
${ }^{24}$ Tradução minha. Artigo 48 da Constituição de Weimar em sua redação original: "[Massnahmen bei Störung von Sicherheit und Ordnung] Wenn ein Land die ihm nach der Reichsverfassung oder den Reichsgesetzen obliegenden Pflichten nicht erfüllt, kann der Reichspräsident es dazu mit Hilfe der bewaffneten Macht anhalten. Der Reichspräsident kann, wenn im Deutschen Reich die öffentliche Sicherheit und Ordnung erheblich gestört oder gefährdet wird, die zur Wiederherstellung der öffentlichen Sicherheit und Ordnung nötigen Massnahmen treffen, erforderlichenfalls mit Hilfe der bewaffneten Macht einschreiten. Zu diesem Zwecke darf er vorübergehend die in den Artikeln 114, 115, 117, 118, 123, 124 und 153 festgesetzen Grundrechte ganz oder zum Teil ausser Kraft setzen. [ ] Von allen gemäss Abs. 1 oder Abs. 2 dieses Artikels getroffenen Massnahmen hat der Reichspräsident unverzüglich dem reichstag Kenntnis zu geben. Die Massnahmen sind auf Verlangen des Reichstags ausser Kraft zu setzen. [ ] Bei Gefahr im Verzuge kann die Landsregierung für ihr Gebiet einstweilige Massnahmen der in Abs. 2 bezeichneten Art treffen. Die Massnahmen sind auf Verlangen des Reichspräsidenten oder des Reichstags ausser Kraft zu setzen."
} 
uma aparência de normalidade constitucional e democrática, análise que Kirchheimer busca difundir com intuito de reverter.

\section{Forma Direito, O papel do Parlamento E a emancipação POLÍTICA: HÁ UM CAMINHO?}

Grandes questões organizam o debate até aqui. Qual papel desempenha o Parlamento na sociedade? Ele é, assim como a forma Estado, a separação de poderes, a forma direito, meros instrumentos a serviço da dominação de uma classe social que toma o poder do Estado? Ou ele é campo de disputa efetiva? Qual é o papel da forma direito na emancipação? Do ponto de vista dos objetos de análise de Kirchheimer, não mais o grande projeto de organização e socialização de bens para toda a sociedade, mas as pequenas e cotidianas decisões políticas; não mais a Assembleia Nacional Constituinte, mas o Parlamento; não mais a existência de um instrumento jurídico capaz de traçar as linhas gerais e os objetivos da ação política - a Constituição -, mas as decisões cotidianas coaguladas em leis, prévias a toda e qualquer ação do Poder Executivo. Aproxima-se a análise da realidade concreta, modificam-se as principais instituições analisadas, bem como as questões políticas das quais elas tratam. $\mathrm{O}$ objeto, no entanto, é semelhante: seria a forma direito - ou a específica forma direito produzida pelo Parlamento - uma importante mediadora entre vontade e ação políticas e a realidade?

A conclusão da obra de Kirchheimer pós-1930 parece ter um sentido claro: Estado e sua teoria não são mais instrumentos exclusivos da burguesia. Apesar de o Parlamento não ter modificado definitivamente sua formulação inicial e sua vinculação de origem à classe burguesa, permitiu aos proletários também recorrer aos mecanismos de organização da sociedade e de tomada de decisões políticas. Ele, Parlamento, e as outras instituições do Estado tripartite teriam se tornado o campo de batalha de uma luta social que antes era travada entre proletariado e burguesia fora de qualquer institucionalidade.

Também o Judiciário contribuiu para a institucionalização dos conflitos sociais e para a sua sujeição à ordem legal. Os contornos jurídicos conformam os conflitos sociais e "domam-nos", tornando-os controláveis e, portanto, menos ameaçadores à ordem instituída. Problemas sociais tornam-se problemas meramente jurídicos e, como tal, são neutralizados e retirados do embate real, físico - caminho que poderia escolher para se expressar. A conflituosidade e o embate aparecem enquanto tais em várias dessas esferas jurídicas, porém.

Esse cenário, no entanto, afirma Kirchheimer, só é plenamente válido quando somente uma classe domina totalmente os instrumentos legais. Quando há conflitos de interesses sociais levados ao Parlamento, é o próprio papel da lei - e com ele o significado do direito - que se modifica. Kirchheimer, então, passa a prever um potencial emancipatório no próprio direito, contrariando sua posição inicial, segundo a qual o afirmava como uma mera ferramenta a serviço da 
burguesia, ou, mais genericamente, da dominação de classe. Seu potencial político ocorre somente quando os representantes dos trabalhadores efetivamente ingressam no Parlamento e dele começam a participar. Os instrumentos institucionais de deliberação e decisão política, então, são passíveis de disputa e não são, em si, totalmente domados pela burguesia. Esta parece ser a primeira conclusão. Tal possibilidade de ação nos limites da ordem legal e institucional carregam em si, além disso, uma série de outras promessas e possibilidades de estratégias de ação política que ocorrem no Estado de Direito, e não apenas por meio de sua supressão.

Em seus primeiros textos, de 1928, Kirchheimer parece afirmar que não haveria na forma direito nenhuma característica a ser preservada ou almejada. Haveria no Estado Parlamentar apenas um equilíbrio de forças historicamente transitório que seria sucedido pela imposição e pelo aumento de forças de um dos lados. Se a classe trabalhadora vencesse, haveria então uma democracia real. Quando tal imposição da força social ocorrer, tal processo não necessariamente será mediado pelo direito.

O Parlamento, por sua vez, teria por função amortecer as forças sociais em conflito, por acrescentar uma instituição intermediária que nada modifica - antes, ao contrário, esconde as reais relações de poder. Kirchheimer defende no início de sua produção, então, que das próprias relações de poder que se deve tratar. Sua avaliação sobre a instituição parece modificar-se quando a capacidade política do Parlamento é esvaziada, não pelas mãos de revolucionários que lutam por uma suposta democracia efetiva e por distribuição de riquezas sociais, mas sim pelos membros do Poder Executivo, que passam a exercer o poder de forma autoritária, contra grupos específicos da sociedade (entre eles judeus, como Kirchheimer), também em nome da concentração de decisões e bens.

Outro desconforto que emerge na obra de Kirchheimer: Defender o Estado Parlamentar acriticamente, defender a democracia formal, seria preocupar-se meramente a emancipação política, ou seja, com impedir a sujeição a governos déspotas e o uso arbitrário do poder. Nenhuma consideração se faz, nessa linha, sobre a necessidade de emancipação social ou econômica para a realização da democracia. Kirchheimer parece fazer, assim, a desconfortável pergunta acerca do significado da emancipação política desvinculada de qualquer requisito social ou econômico que garanta a participação. Em uma determinada sociedade política que respeite as liberdades públicas e o direito universal ao voto, qual a influência da capacidade econômica na possibilidade de exercício efetivo do uso do poder? Como esquivar-se da constatação constante - também em Weimar - de que o exercício do poder político e o exercício do poder econômico caminham lado a lado?

Kirchheimer especula ainda em Para uma Teoria do Estado do Socialismo e do Bolchevismo que em uma sociedade mais igualitária já não existiria o Estado representativo, já não sendo cabível discutir os parâmetros do Estado 
Parlamentar. A conclusão seria parecida com "para o Estado Parlamentar funcionar de maneira propriamente democrática, a organização social e econômica da sociedade deveria ser tal que o Estado como tal já não existiria".

Tal paradoxo, nesse texto retomado por Kirchheimer, torna explícita a dificuldade da discussão: ao acrescentar valores à democracia parlamentar, acabase por negar totalmente seu modelo e, em seu lugar, não parece haver alternativas formuladas. Há uma democracia de resultado, em que todo o povo seria igual e viveria bem, mas para este mundo igual e sem Estado haveria um vácuo de formulação sobre como seria o exercício do poder compartilhado. Seria descentralizado, é certo. Seria democrático, também é certo. Mas como realizá-lo em estruturas tão complexas de sociedade, em aglomerados urbanos que requerem ao menos uma administração dos espaços coletivos?

Outro fator interessante pode ser extraído do paradoxo apontado: se as condições para que a democracia se realize são tão ambiciosas a ponto de não caberem em uma organização política centralizada como o Estado, o que fazer com as conquistas que foram feitas essencialmente em seu âmbito - constituição que limita o âmbito de atuação daquele que detém o poder, liberdades públicas, possibilidade de crítica e de resistência à ordem vigente? Há conquistas liberais quase completamente identificadas com o Estado. Deve-se prescindir delas em nome de um estado de coisas que se pretende no resultado mais "democrático", por estar ele mais perto do que deveriam ser - a partir de um parâmetro racional - os anseios da maior parte da população? Como garantir que o que se formula como o melhor para a maioria realmente o é, sem recorrer aos procedimentos democráticos? E, uma vez implementada essa sociedade, o exercício do poder não seria limitado de nenhuma forma?

Ao reduzir o político ao social, aponta Kirchheimer, perde-se o que há de especificamente político na discussão. Kirchheimer parece defender não ser possível ignorar que a luta contra a opressão política faz parte da história da humanidade; essa luta tem curso próprio e, em alguma medida, autônomo em relação à discussão sobre as opressões econômicas e sociais. Esquecer que uma das formas de sujeição humana é a sujeição política para lutar contra opressões sociais e econômicas, parece-lhe, seria um erro de análise histórica, tão cara à metodologia de interpretação da realidade que tem Marx como referencial.

Apesar de suas imensas queixas em relação às limitações de transformação nos limites do sistema jurídico e em sua específica forma de distribuir o poder, Kirchheimer se afasta da condenação pura e simples do instrumento jurídico. Faz coro, segundo ele, com a própria avaliação dos movimentos que lutam pela transformação da sociedade: eles reconhecem que está garantida, pelo direito, a possibilidade de ser ouvido e considerado. A capacidade de fala, de manifestação, que a forma jurídica possibilita é valorada positivamente. $\mathrm{O}$ mesmo mecanismo que esconde e intermedeia a decisão política de seus destinatários, criando um entreposto mais difícil de atingir e modificar, é o que estabelece mecanismos de 
participação e evita a supressão do ato de fala do sujeito político. Aqui, neste texto de 1930, ainda tão crítico à Constituição de Weimar (nele é forjada a expressão "constituição sem decisão"), Kirchheimer vislumbra pontos positivos e manifesta certa simpatia pelo mecanismo jurídico de regulação da sociedade, com todas as suas limitações, mas também com suas garantias de liberdade e procedimento que, de alguma forma, representaram um avanço contra o exercício puramente arbitrário do poder. A específica forma de emancipação política de um sistema que garante a participação política e liberdades públicas - e a não submissão ao exercício do poder ilimitado e que, por isso pode ser arbitrário estão envolvidas nessas reflexões.

Se Kirchheimer considerava graves as decisões políticas em prol da coalizão tomadas pelo Partido Social-Democrata Alemão (SPD) em 1919, que geraram uma constituição dividida em duas, e se, no mesmo sentido, via no instrumento jurídico um mero neutralizador dos conflitos sociais, no decorrer dos seus trabalhos matiza a ênfase de suas posições: afinal, são os próprios movimentos de transformação da sociedade que viam na possibilidade de participação garantida pelo instrumento jurídico um valor a ser defendido. Talvez não fosse possível ou não fosse almejável - abdicar das proteções, ainda que modestas e falhas, que a Constituição previa, ou que foram forjadas pelas lutas liberais de mais de um século antes.

Do ponto de vista metodológico, Kirchheimer parece passar a separar em dois campos distintos os avanços civilizatórios: de um lado, devem-se buscar a distribuição dos meios de produção e o fim das desigualdades e opressões socioeconômicas - o tipo de emancipação aqui poderia ser caracterizado como social, por outro lado, quase em recusa à tese forte marxista sobre a separação entre infraestrutura e superestrutura, parece haver um campo específico de emancipação política: a preservação da liberdade individual frente àqueles que exercem o poder - e que devem ser limitados para não usarem seu poder arbitrariamente. O campo do debate do político não está, nessa análise, totalmente abarcado pelo social. Há uma especificidade da emancipação política - ainda não completa no Estado Parlamentar - que a distingue da emancipação social. Ambas se complementam, e, provavelmente uma não se realiza plenamente sem a outra. Mas é exatamente por isso que a específica emancipação política não pode ser suprimida para que a emancipação social seja realizada.

Essa talvez seja a principal diferença teórica. Enquanto no início, o objetivo final também era a participação de todos em uma forma de organização da sociedade em que o poder não seria concentrado, sendo o caminho para alcançar esta sociedade democrática marcado pela suspensão da ordem existente e pela apropriação autoritária do Estado Parlamentar desenvolvido - afinal de contas, todos os estados organizados guardavam, na verdade, um elemento de dominação de classe; a diferença no caso da ditadura do proletariado estaria simplesmente em ser uma classe distinta da economicamente dominante -, ao 
final do período Kirchheimer já não admitia que o meio para alcançar a "verdadeira" democracia fosse a ditadura, uma vez que estruturas autoritárias de organização, para conseguirem alcançar o poder e realizar seus objetivos, levam a regimes que, após implementados, tendem a se perpetuar autoritários.

Essa mudança essencial trouxe impacto também nas características do conceito trabalhado ao longo deste artigo. Se no início Kirchheimer aproximava-se do decisionismo de Schmitt, cobrando da Constituição de Weimar uma decisão clara sobre o embate polarizado então em voga (Weimar... e então, 1930), decisionismo esse avesso a acordos políticos de coalizão (e soluções intermediárias de organização política da sociedade), em seus textos finais o autor parece constatar que, por vezes, a composição de interesses conflitantes, a proposta intermediária são as que melhor representam um determinado momento político de uma determinada sociedade política. Acordos conciliatórios podem ser democráticos.

Não há necessidade de aprofundar as conclusões a que Kirchheimer chega quanto à ditadura do proletariado - antes tida como possibilidade tática real - $\mathrm{e}$ quanto à instrumentalidade da democracia: uma vez que esta passa ser componente essencial de uma determinada forma de emancipação humana ainda que não plena -, emancipação que se refere especificamente ao exercício do poder político, as hipóteses e casos em que a sua supressão é admitida mínguam. Apesar disso, Kirchheimer não dá resposta definitiva ao principal problema: como negar que, mesmo com a presença dos mecanismos formais de participação, haja identidade entre poder econômico e poder político? Para o enfrentamento do desigual poder econômico, ainda assim é melhor contar com as garantias das liberdades públicas do que ficar sem elas, parece afirmar.

Por fim, ao discutir os pressupostos, mecanismos técnicos e avaliação por resultado, mantém a maioria de suas posições, acrescentando diversos elementos ao conceito formal de democracia. Não recorre a eles, no entanto, para ir tão longe: ao final do período o que está em questão é sempre o aprimoramento da organização democrática existente do poder, não pressupostos anteriores necessários à realização da democracia, que justificariam sua supressão para a construção de algo inteiramente novo. Momentos de ausência de garantias formais contra a arbitrariedade no exercício do poder são analisados com temor - e, portanto, com mais ressalvas do que no início do período.

Kirchheimer constata também que a democracia formal é sempre frágil; depende, de alguma forma, de o antagonismo de forças não ser tão grande a ponto de esgarçar o sistema. Nesse contexto, a democracia deve ser defendida, uma vez que sua supressão - seja para a dominação do proletariado, seja para a dominação da burguesia - traz sempre consequências nefastas, independentemente de quão nobres sejam os objetivos pretendidos. 


\section{CONSIDERAÇõES FINAIS}

É o Parlamento que está em destaque na obra de Kirchheimer sobre a República de Weimar. Quer para criticar a escolha pelo Parlamentarismo nas decisões da Assembleia Nacional Constituinte, quer para defendê-lo do Poder Executivo que promovia o saque de suas competências, referendado pelo Poder Judiciário, é esta a instituição que tem centralidade na análise.

Kirchheimer se dedica inicialmente à transformação do significado do Parlamento na Alemanha desde a unificação promovida por Bismarck, período anterior à Primeira Guerra Mundial, quando ao Parlamento era reservado um significado político bastante restrito, e, posteriormente, a seu desenrolar ao longo da República de Weimar. O que em Kirchheimer era uma crítica pela covardia ou timidez política de se ter escolhido o Parlamento como instituição capaz de promover a democracia em 1918-1919, transformou-se em defesa do Parlamento inclusive por sua capacidade de promover a democracia - frente a um Executivo concentrador e que já apresentava sinais de autoritarismo e desrespeito à legalidade.

Sobre a discussão acerca dessa específica capacidade institucional, Kirchheimer afirma, em Mudança do Significado do Parlamentarismo (1928), ter sido a própria concepção originária do Parlamento não democrática. Dele participavam apenas as pessoas de posses e cultura - para responder aos anseios da burguesia, que se fortalecia em seu poder econômico, frente à nobreza e à monarquia que então monopolizavam o poder político. Não havia, no entanto, preocupação com a participação política daqueles que não pertenciam a nenhum desses grupos.

O Parlamento, então, segundo a leitura que dele faz Kirchheimer, teria sido uma instituição criada para satisfazer os interesses e desejos de participação política de um determinado grupo: a burguesia proprietária. Para isso, o recurso ao voto censitário, que equacionava a possibilidade de escolher representantes de acordo com as propriedades daquele que votava, foi uma solução eficaz por um período. A convivência pacífica entre o Parlamentarismo e mecanismos censitários de sopesamento de votos (ou mesmo exclusão de parcelas da população do direito de votar) evidenciaria, assim, um vício de origem em suas possibilidades de realização democrática: ele não teria sido idealizado para alcançar esse fim.

Decorrente dessa composição parlamentar pode-se depreender outro traço distintivo do Parlamento: ele seria uma instituição em que um conjunto de representantes de diversas - ou não tão diversas assim - partes da sociedade seriam capazes de tomar as melhores decisões para a vida coletiva selecionadas por meio de discussões racionais. Tais discussões, por sua vez, são também a base de sua legitimidade, uma vez que promovem as melhores decisões possíveis, sendo sua supremacia sobre as outras descoberta racionalmente. O próprio Estado de Direito, bem como a correspondente separação de poderes, bebe na mesma fonte de legitimidade. É o Parlamento, democrático, local de decisões racionais, que oferece parâmetros legítimos para a ação dos poderes Executivo e Judiciário. 
No entanto, a partir da implantação do sufrágio universal, houve uma mudança político-institucional relevante no Parlamento. A forma óbvia e direta de afastar a maioria da população das decisões políticas relevantes - selecioná-las por suas rendas - não mais existia como possibilidade. No novo contexto, recorria-se, afirma Kirchheimer, a outros mecanismos, tais como o monopólio da imprensa e as dificuldades financeiras para se realizar uma campanha eleitoral. Esses, no entanto, não tão efetivos quanto o voto censitário, não impediam a representação de classes populares no Poder Legislativo.

Com a presença de diferentes classes e interesses no Parlamento, transformouse o significado desta instituição. A discussão racional não mais poderia ali acontecer. Aliás, discussões em si não seriam mais possíveis, uma vez que há efetiva polarização de interesses colocada. As discussões, então, foram exteriorizadas e o Parlamento tornou-se um local onde se declaram posições e se medem as forças de cada uma das hipóteses cogitadas. Esse cenário - que se apresenta para Kirchheimer em um momento concreto da República de Weimar revela a possibilidade de, por meio da ação parlamentar, ver modificadas algumas das características estruturantes da sociedade alemã de então.

Kirchheimer, no início de seus textos bastante cético com as possibilidades democráticas da instituição Parlamento, ao vê-lo efetivamente atacado por forças que considerava conservadoras, passa a reconsiderar sua avaliação. A investida concreta contra o poder e as competências do Parlamento em Weimar ilumina possibilidades transformadoras nessa instituição na análise de Kirchheimer, que passa a defendê-lo.

O objeto de sua defesa, no entanto, não é a instituição parlamentar abstrata, mas a historicamente existente, imbuída dos poderes conferidos pela Constituição de Weimar, inclusive no que se refere à sua capacidade de legislar e regular, por meio de maioria simples, a propriedade privada (entre outros temas, esse foi aquele ao qual o autor mais detidamente se dedicou). No entanto, para justificar a inflexão de sua posição política em relação ao Parlamento, Kirchheimer elabora algumas justificativas acerca da importância da forma de representação possibilitada por esse Parlamento.

Ao opor o Parlamento ao Poder Executivo, notadamente ao Presidente, identifica algumas diferenças, a começar pela forma de eleição do representante. Enquanto na eleição presidencial apenas um é escolhido - e, portanto, é preciso realizar alianças e composições para tornar um candidato viável em oposição a outros, reduzindo os programas dos partidos e das forças políticas envolvidas a um mínimo comum -, no Parlamento, por serem muitos os eleitos, não há necessidade de redução do programa para viabilizar uma candidatura. $\mathrm{O}$ próprio processo eleitoral, assim, majoritário-plebiscitário em um caso e proporcional em outro, promove uma representação política parlamentar mais fiel aos anseios políticos daqueles que votam e elegem seus representantes. 
Ainda sobre as diferenças entre Executivo e Legislativo, é relevante ressaltar o tempo das decisões - e a possibilidade de participação pública fora dos limites institucionais - como fatores de democratização do Parlamento. Para aprovação de uma lei é necessário um processo legislativo que demanda tempo e, nesse tempo, é natural que o objeto da regulação seja discutido em outros âmbitos que não apenas o institucional. Já no Executivo, não há procedimentos claros para tomada de decisão, o que significa que ela não passa por um rito previamente conhecido até ser tomada, podendo ser escolhida imediatamente. Tal fato impede uma discussão para além dos muros do governo. Sem discussão pública, é impossível a participação e influência de agentes não estatais nas decisões políticas fundamentais, diminuído, assim, seu potencial democrático.

Esses três traços da instituição parlamentar - eleições não majoritáriasplebiscitárias, que permitem a maior aproximação da representação da opinião política dos eleitores; procedimentos para tomada de decisão legislativa dilatada no tempo; possibilidade, em função das duas anteriores, dos debates extrapolarem os limites institucionais - conferem em tese ao Parlamento maior capacidade democrática do que aos seus pares na separação de poderes, Executivo e Judiciário. Tal potencial democrático, no entanto, deve ser avaliado na realidade concreta dos parlamentos existentes, sobretudo em suas composições. Ocorre que, na realidade concreta de Weimar, tanto a composição quanto as decisões aproximaram-se de anseios populares, havendo efetiva disputa no seio do Parlamento.

$\mathrm{E}$, exatamente no momento em que se descortinou uma possibilidade democrática no Poder Legislativo, este foi esvaziado politicamente e expropriado de sua capacidade decisória. Quando as decisões tomadas em seu seio passaram a ameaçar aqueles que se beneficiavam da manutenção do estado de coisas tal como estavam, a solução parece ter sido retirar do Parlamento a importância política que ele poderia ter. Ou seja, em um modelo de Parlamento clássico - tal como idealizado no fim do século XVII - controla-se a participação na instituição, reservando-a, nas palavras de Kirchheimer, às pessoas de propriedades e cultura. Seriam elas as capazes de promover a discussão racional e acordar quais seriam as melhores medidas em prol do bem de toda a sociedade. Quando o controle da participação deixa de ser efetivo - dificultado com a garantia do voto universal passa-se então a enfraquecer o significado político do Parlamento. As decisões políticas mais relevantes seriam, nesse contexto, transferidas a um espaço de deliberação exterior à instituição.

No entanto, a específica forma de justificação de um Estado constitucional - ao contrário de ordens de poder fundadas no carisma e na tradição - é o fato de o poder ser exercido de forma limitada e balizada por normas que ele próprio não produziu. A produção normativa do Poder Legislativo, nesse contexto, é elemento fundamental para legitimação do exercício do poder no Estado de Direito, não podendo ser suprimida impunemente sem que tal legitimação seja afetada ou afastada. 
A própria supressão da legalidade - inclusive de sua aparência - era o que estava em questão na República de Weimar. Dissoluções parlamentares imotivadas e poderes excepcionais/permanentes conferidos ao Presidente compunham a situação de limiar de validade do específico sistema de justificação fundado na legalidade do Estado de Direito. Nesse momento extremo, a separação de poderes revelava seu valor: a concentração decisória servia à implementação da arbitrariedade e da imposição por meio da força das razões de uma parcela da população, que arrogava para sua posição um consenso inexistente. A parcela da população que dela divergia era esmagada por sua força, policial inclusive, sem poder se organizar. Nesse contexto, está a importância das liberdades públicas para a possibilidade democrática, importância que deve ser registrada.

Não só o embate entre Parlamento e Executivo compunha a supressão das competências legislativas - apesar de ser, sem dúvida, o mais evidentemente problemático. Kirchheimer também aborda as relações entre esses dois poderes e o Judiciário. Quando os membros da magistratura se recusam a contrariar decisões do Executivo, por um lado, e a respeitar as decisões do Legislativo, por outro, o poder, que já estava concentrado no Executivo alcança uma unidade prática. O tema mais discutido por Kirchheimer - que também ocupava lugar de destaque na organização da República que sucumbia - era o da regulação e limitações à propriedade. A proteção aos direitos patrimoniais, contrariando o "espírito" da Constituição de Weimar e deixando sem validade inúmeras normas editadas pelo Legislativo, estava em questão. Propriedade, por outro lado, tem relação com capacidade de intervenção política. O ciclo, então, se realimenta: atua politicamente quem tem capacidade econômica para tanto; o poder, por sua vez, é exercido para que se mantenham os privilégios econômicos já existentes.

Uma constituição que não garante o ciclo - a propriedade na Constituição de Weimar estava pouco protegida quer pelo texto normativo, amplo o suficiente para não impedir a atuação legislativa, quer pelo processo legislativo, já que regulações sobre o direito de propriedade não dependiam de quórum qualificado para serem aprovadas: a maioria simples poderia limitá-lo. Tal "falha de proteção" constitucional era "corrigida" pelo Poder Judiciário, que não conferia eficácia às normas que haviam sido editadas pelo Parlamento no período.

Quando nem mesmo a aparência de legalidade era respeitada pelo Poder Executivo, quando o ataque ao Parlamento era realizado pelos dois outros poderes, revela-se claramente que a existência, a composição e a legislação derivada do Parlamento de Weimar efetivamente ameaçavam os interesses da parcela de proprietários da sociedade. É o ataque que valoriza e realça as possibilidades da instituição na leitura de Kirchheimer, que, nesse ponto, não tem mérito de predição. É a ofensiva sobre o Parlamento que reforça as razões de sua defesa.

Enquanto o Executivo buscava se legitimar por meio do suposto consenso em torno de suas posições, se afastava da legalidade. Denunciar a falácia da democracia possível por meio do Parlamento não fazia mais sentido, tendo em vista 
a falta exatamente da mediação legislativa do exercício do poder. Quando o poder concreto existente é truculento, autoritário e concentrador, as posições divergentes gostariam de poder recorrer à intermediação do Poder Legislativo que lhes garante, ao menos, espaço institucional e capacidade de fala. $\mathrm{O}$ massacre e a supressão completa de suas vozes não estão no horizonte em um Estado Democrático Parlamentar, ainda que a possibilidade de a população majoritária tornar-se politicamente majoritária e realizar seus anseios de organização social não esteja claramente (ou automaticamente) assegurada por meio do Parlamento.

As relações sociais em que o poder se concentra em camadas minoritárias da população são a regra, desde o surgimento do Estado Parlamentar. O que ele oferece especificamente para a democracia são questões importantes para pensar o potencial emancipatório da forma direito.

\section{REFERÊNCIAS BIBLIOGRÁFICAS}

\section{TEXTOS DE OTTO KIRCHHEIMER EM ORDEM CRONOLÓGICA}

\section{Para uma Teoria do Estado do Socialismo e do Bolchevismo (1928)}

KIRCHHEIMER, Otto. Zur Staatslehre des Sozialismus und Bolschewismus. In Von der Weimarer Republik zum Faschismus: Die Auflösung der demokratischen Rechtsordnung. LUTHARDT, Wolfgang (organizador). Editora Suhrkamp, Frankfurt am Main, 1976, pp. 32-52.

The Socialist and Bolshevik Theory of the State. In Politics,

Law, and Social Change - Selected Essays of Otto Kirchheimer. BURIN, Frederic S. e SHELL, Kurt L. (Editores), Columbia University Press. New York, 1969. Pp. 3-21.

\section{Cruzador Couraçado e o Direito Público (1928)}

. Panzerkreuser und Staatsrecht. In Otto Kirchheimer Von der

Weimarer Republik zum Faschismus: Die Auflösung der demokratischen Rechtsordnung. Wolfgang Luthardt (organizador). Editora Suhrkamp, Frankfurt am Main, 1976, pp. 53-57.

\section{Mudança de Significado do Parlamentarismo (1928)}

. Bedeutungswandel des Parlamentarismus. In Otto

Kirchheimer Von der Weimarer Republik zum Faschismus: Die Auflösung der demokratischen Rechtsordnung. Wolfgang Luthardt (organizador). Editora Suhrkamp, Frankfurt am Main, 1976, pp. 58-63.

. \& Tavolari, B. (2018). Mudança de significado do 
parlamentarismo. Cadernos De Filosofia Alemã: Crítica E Modernidade, 23(1), 155159. https://doi.org/10.11606/issn.2318-9800.v23i1

\section{O Problema da Constituição (1929)}

. Das Problem der Verfassung. In Otto Kirchheimer Von der Weimarer Republik zum Faschismus: Die Auflösung der demokratischen Rechtsordnung. Wolfgang Luthardt (organizador). Editora Suhrkamp, Frankfurt am Main, 1976, pp. 64-68.

\section{Realidade Constitucional e Futuro Político da Classe Trabalhadora (1929)}

Verfassungswirklichkeit und politische Zukunft der Arbeiterklasse. In Otto Kirchheimer Von der Weimarer Republik zum Faschismus: Die Auflösung der demokratischen Rechtsordnung. Wolfgang Luthardt (organizador). Editora Suhrkamp, Frankfurt am Main, 1976, pp. 69-76.

Weimar - e então? Análise de uma constituição (1930) . Weimar - und was dann? Analyse einer Verfassung. In Politik und Verfassung. Editora Suhrkamp, Frankfurt am Main, 1964, pp. 9-56

. Weimar - and what then? - An Analysis of a Constitution.

In Politics, Law, and Social Change - Selected Essays of Otto Kirchheimer. BURIN, Frederic S. e SHELL, Kurt L. (Editores), Columbia University Press. New York, 1969. Pp. 33-74.

Otto Kirchheimer. Weimar... e então? Formação e atualidade da Constituição de Weimar. Tradução de Bianca Tavolari. Direito e Práxis, n. 2, v. 10, 2019. P. 1512-1553. DOI: 10.1590/2179-8966/2019/42606

Os Limites da Desapropriação: Uma Contribuição para a História do Desenvolvimento do Instituto da Desapropriação e para a Interpretação do Artigo 153 da Constituição de Weimar (1930)

. Die Grenzen der Enteignung: Ein Beitrag zur

Entwicklungsgeschichte des Enteignungsinstituts und zur Auslegung der Art. 153 der Weimarer Verfassung. In Otto Kirchheimer Funktionen des Staats und der Verfassung: 10 Analysen. Editora Suhrkamp, Frankfurt am Main, 1972, pp. 223-295. 
por Leena Tanner e Keith Tribe. London: Allen \& Unwin: 1987. pp. 85-129.

O Artigo 48 e as Modificações do Sistema Constitucional. Também uma contribuição para o dia da Constituição (1930)

Artikel 48 und die Wandlungen des Verfassungssystems.

Auch ein Beitrag zum Verfassungstag, In Von der Weimarer Republik zum Faschismus: Die Auflösung der demokratischen Rechtsordnung. LUTHARDT, Wolfgang (organizador). Editora Suhrkamp, Frankfurt am Main, 1976, pp. 91-112.

Garantia da Propriedade na Constituição e na Jurisprudência (1930)

. Eigentumsgarantie in Reichsverfassung und

Rechtsprechung. In Otto Kirchheimer Funktionen des Staats und der Verfassung: 10 Analysen. Editora Suhrkamp, Frankfurt am Main, 1972, pp. 7-27.

Tribunal Constitucional do Reich e Desapropriação. Inconstitucionalidade da Lei de Zoneamento Prussiana? (1930)

. Reichsgericht und Enteignung.

Reichsverfassungswidrigkeit des Preußischen Fluchtliniengesetzes?. In Otto Kirchheimer Von der Weimarer Republik zum Faschismus: Die Auflösung der demokratischen Rechtsordnung. Wolfgang Luthardt (organizador). Editora Suhrkamp, Frankfurt am Main, 1976, pp. 91-95.

Os Problemas da Dissolução do Parlamento para o Estado de Direito (1932) . Die staatsrechtlichen Probleme der Reichstagauflösung. In Otto Kirchheimer Funktionen des Staats und der Verfassung: 10 Analysen. Editora Suhrkamp, Frankfurt am Main, 1972, pp. 28-41.

\section{A Reforma Constitucional (1932)}

. Die Verfassungsreform. In Otto Kirchheimer Von der Weimarer Republik zum Faschismus: Die Auflösung der demokratischen Rechtsordnung. Wolfgang Luthardt (organizador). Editora Suhrkamp, Frankfurt am Main, 1976, pp. 96-112.

Legalidade e Legitimidade (1932)

. Legalität und Legitimität . In Politische Herschaft - Fünf

Beitrage zur Lehre vom Staat. Editora Suhrkamp, Frankfurt am Main, 1967, pp. 7-29. 
. Legality and Legitimacy. Trad. Anke Grosskopf and

William Scheuerman. In The Rule of Law under Siege - Selected Essays of Franz L. Neumann and Otto Kirchheimer. SCHEUERMAN, William E. (Editor). University of California Press. Pp. 44-63.

\section{A Teoria Constitucional do Conflito Prussiano (1932)}

. Die Verfassungslehre des Preußen-Konflikts. In Otto

Kirchheimer Funktionen des Staats und der Verfassung: 10 Analysen. Editora

Suhrkamp, Frankfurt am Main, 1972, pp. 42-61.

\section{Reação Constitucional 1932 (1932)}

Verfassungsreaktion 1932. In Otto Kirchheimer Funktionen des Staats und der Verfassung: 10 Analysen. Editora Suhrkamp, Frankfurt am Main, 1972, pp. 62-78.

. Constitutional Reaction in 1932. In Politics, Law, and Social Change - Selected Essays of Otto Kirchheimer. BURIN, Frederic S. e SHELL, Kurt L. (Editors). Columbia University Press. New York, 1969. Pp. 75-87.

Comentários sobre o 'Legalidade e Legitimidade' de Carl Schmitt (1933)

Bemerkungen zu Carl Schmitts "Legalität und Legitimität",

In Von der Weimarer Republik zum Faschismus: Die Auflösung der demokratischen Rechtsordnung. LUTHARDT, Wolfgang (organizador). Editora Suhrkamp, Frankfurt am Main, 1976, pp. 113-151.

. Remarks on Carl Schmitt's Legality and Legitimacy. Trad.

Anke Grosskopf and William Scheuerman. In The Rule of Law under Siege - Selected Essays of Franz L. Neumann and Otto Kirchheimer. SCHEUERMAN, William E. (Editor). University of California Press. Pp. 64-98.

\section{Reforma Constitucional e Social Democracia (1933)}

. Verfassungsreform und Sozialdemokratie. In Otto

Kirchheimer Funktionen des Staats und der Verfassung: 10 Analysen. Editora Suhrkamp, Frankfurt am Main, 1972, pp. 79-99.

. Constitutional Reform and Social Democracy. In Social Democracy and the Rule of Law - Otto Kirchheimer and Franz Neumann. Keith Tribe (Editor). Traduzido por Leena Tanner e Keith Tribe. London: Allen \& Unwin: 
1987. pp. 85-129.

Marxismo, Ditadura e Forma de Organização do Proletariado (1933)

. Marxismus, Diktatur und Organizationsform des

Proletariats. In Otto Kirchheimer Funktionen des Staats und der Verfassung: 10 Analysen. Editora Suhrkamp, Frankfurt am Main, 1972, pp. 100-114.

. Marxism, Dictatorship, and the Organization of the

Proletariat. In Politics, Law, and Social Change - Selected Essays of Otto Kirchheimer. BURIN, Frederic S. e SHELL, Kurt L. (Editores), Columbia University Press. New York, 1969. Pp. 22-32.

Ascensão e Queda da Constituição de Weimar (1933)

. The Growth and the Decay of the Weimar Constitution. In The

Contemporary Review, Vol. 144, n. 2, 1933, No. 815/Nov. 1933, pp. 559-567.

\section{BIBLIOGRAFIA GERAL}

BERCOVICI, Gilberto. Constituição e estado de exceção permanente. Rio de Janeiro: Azougue Editorial, 2004.

direito,

. Entre o Estado Total e o Estado Social - Atualidade do debate sobre

Estado e economia na República de Weimar. São Paulo, 2003. Tese (Livre

Docência) -

Faculdade de Direito, Universidade de São Paulo.

Paulo:

. Soberania e constituição: Para uma Crítica do Constitucionalismo. São

Quartier Latin, 2008.

BOLAFFI, Angelo. Il Crepuscolo della Sovranitá. Donzelli Editore. Roma: 2002.

FARIA, José Eduardo. Crise Constitucional e Restauração da Legitimidade. Porto Alegre: Fabris, 1985.

. Entre a Rigidez e a Mudança: A Constituição no Tempo. in Revista Brasileira 
de Direito Constitucional n. 06, São Paulo, nov/2003.

. Poder e Legitimação (uma introdução à política do direito). São Paulo: Editora

Perspectiva. 1978.

HERZ, John H. and HULA, Erich. Otto Kirchheimer - An Introduction to His Life and Work. In Politics, Law, and Social Change - Selected Essays of Otto Kirchheimer. BURIN, Frederic S. e SHELL, Kurt L. (Editors). Columbia University Press. New York, 1969.

HONNETH, Axel. Teoria Crítica. In GIDDENS, Anthony e TURNER, Jonathan (Org.) Teoria Social Hoje. Editora Unesp, 1a. Reimpressão. Pp. 503-552.

HORKHEIMER, Max. Teoria Tradicional e Teoria Crítica. In Coleção Os Pensadores - Horkheimer Adorno. Ed. Abril Cultural, 1980. pp. 117-161

JAY, Martin. The Dialectical Imagination - A History of the Frankfurt School and The Institute of Social Research 1923-1950. University of Califórnia Press.

. Reconciling the Irreconcilable? Rejoinder to Kennedy. In Telos n. 71 Primavera de 1987. Telos Press, Nova Iorque: 1987. Pp. 67-80.

KELLY, Duncan. The State of the Political - Conceptions of Politics and the State in the Thought of Max Weber, Carl Schmitt and Franz Neumann. Oxford University Press. Nova Iorque: 2003.

KENNEDY, Ellen. Carl Schmitt and The Frankfurt School. In Telos n. $71-$ Primavera de 1987. Telos Press, Nova Iorque: 1987. Pp. 37-66.

. Carl Schmitt and The Frankfurt School: A Rejoinder. In Telos n. 73 - Outono de 1987. Telos Press, Nova Iorque: 1987. Pp. 101-116.

LOUREIRO, Isabel. A Revolução Alemã 1918-1923. São Paulo: Editora Unesp, 2005. Coleção Revoluções do Séc. XX.

LUTHARDT, Wolfgang. Bemerkungen zu Otto Kirchheimers Arbeiten bis 1933, In Von der Weimarer Republik zum Faschismus: Die Auflösung der demokratischen Rechtsordnung. LUTHARDT, Wolfgang (organizador). Editora Suhrkamp, Frankfurt am Main, 1976, pp. 7-31.

MACEDO JR, Ronaldo Porto. Carl Schmitt e a Fundamentação do Direito. A Formação do Decisionismo Institucionalista Schmittiano entre os anos 1920 e 
1940. Max Limonad, 2001.

MACHADO, Maíra Rocha; RODRIGUEZ, José Rodrigo. Otto Kirchheimer: uma contribuição à crítica do direito penal (Levando o direito penal a sério). In: Marcos Nobre (Org.). Curso Livre de Teoria Crítica. Campinas: Papirus, 2008. p. 117-136.

NOBRE, Marcos (Org). Curso Livre de Teoria Crítica. Campinas, SP: Papirus, 2008.

OFFE, Claus. "A democracia partidária competitiva e o 'welfare state' keynesiano: fatores de estabilidade e desorganização", em Problemas estruturais do estado capitalista. Rio de Janeiro: Tempo Brasileiro, 1984.

RIZZI, Ester Gammardella. Democracia e transformações sociais no Estado parlamentar: Kirchheimer e a República de Weimar. Dissertação de mestrado apresentada à Faculdade de Direito da Universidade de São Paulo, 2011. Disponível em: <http://www.teses.usp.br/teses/disponiveis/2/2139/tde-24042012110644/publico/Ester Gammardella Rizzi.pdf $>$. Consulta realizada em 02 de dezembro de 2021.

Qual é a forma jurídica da nova ordem social? Reflexões a partir da obra de Otto Kirchheimer sobre a Constituição de Weimar. In: Gilberto Bercovici. (Org.). Cem anos da Constituição de Weimar (1919-2019). 1ed. São Paulo: Quartier Latin do Brasil, 2019, v. 1, p. 393-429.

RODRIGUEZ, José Rodrigo. A Fuga do Direito: um estudo sobre o direito contemporâneo a partir de Franz Neumann. São Paulo: Saraiva, 2009.

SANTOS, Wanderley Guilherme dos. Poliarquia 3 D. Revista Dados 41 (2) • 1998 Disponível em:

https://www.scielo.br/j/dados/a/H5WXcbFfmrpb8VwyckmqhnC/?lang=pt\#

SAZBON, José. O legado Teórico da Escola de Frankfurt. In Teoria e Filosofia Política: Recuperação dos Clássicos no Debate Latino Americano. Alvaro DE VITA e Atilio A. BORON (orgs.). São Paulo: Editora da Universidade de São Paulo, Buenos Aires, Clacso, 2004.

SCHEUERMAN, William. Between the Norm and The Exception : the Frankfurt School and The rule of law. Massachusetts Institute of Technology, 1997. . Introduction. In The Rule of Law under Siege - Selected Essays of Franz L. Neumann and Otto Kirchheimer. SCHEUERMAN, William E. (Editor). University of California Press. Pp. 1-25. 
SCHMITT, Carl. Legalidad y Legitimidad. Trad. José Diaz García, Aguilar Ediciones, Madrid, 1971, (original Legalität und Legitimität publicado em 1932).

SOELLNER, Alfons. Beyond Carl Schmitt: Political Theory in the Frankfurt School. In Telos n. 71 - Primavera de 1987. Telos Press, Nova Iorque: 1987. Pp. 8196.

Disciples de Gauche de la Revolution Conservatrice: La Theorie Politique D'Otto Kirchheimer et de Herbert Marcuse dans les Dernieres Annees de la Republique de Weimar. In Weimar ou L'Explosion de la Modernité. Éditions Anthropos, Paris: 1984. Pp. 113-128.

TAVOLARI, Bianca M. D. Origens da juridificação: teoria crítica e direito. Orient. José Eduardo Faria. Tese de Doutorado apresentada à Faculdade de Direito da Universidade de São Paulo, 2019.

José Eduardo Campos de Oliveira Faria. Weimar... e então? Uma breve apresentação ao texto de Otto Kirchheimer. Direito e Práxis, n. 2, v. 10, 2019. P. 1500-1512. DOI: 10.1590/21798966/2019/42606

THORNHILL, Chris. Political Theory in Modern Germany - An Introduction. Capítulo 3: Franz Neumann and Otto Kirchheimer. Polity Press, Cambridge UK: 2000. Pp. 92-129.

TRIBE, Keith. Introduction. In Social Democracy and the Rule of Law - Otto Kirchheimer and Franz Neumann. Keith Tribe (Editor). London: Allen \& Unwin: 1987. Pp. 1-26. 